\title{
各種ミニインプラントの䁒床席用および今後の展望について
}

武居 純

\section{Clinical Application of Mini-Implants and Consideration of Their Future Prospect}

\author{
Jun Takesue
}

Mini-implants, often referred to as temporary anchorage devices, have become an accepted component of orthodontic treatment.

Morever, mini-implants for denture stabilization also become an excellent solution for the problem of loose fitting denture.

The author have been experienced a large number of mini-implants cases and achieved favorable outcomes. Furthermore, mini-implants can be applied for another use. For example, the author often applied this mini-implants for temporary anchorage devices to receive a removable partial denture in a healing period when placing osseointegreted implant. If the placed mini-implants receive all the occlusal forces, osseointegrated implant can be protected from any occlusal forces until osseointegration is achieved.

There are a number of case reports in the literature on complications caused by the placement and use of mini-implants. In the coming years, more case reports and randomized studies will likely demonstrate that the benefits of mini-implants, thus allowing the clinicians to expand the treatment options for all patients.

昨今，ミニインプラント（マイクロインプラントまたはミニスクリュー）は，一般臨床 にも多く応用され，安定した治療結果を実現してきている。

現在ミニインプラントには大きく分けて, 矯正治療用のアンカレッジとして暫間的に用 いられるものと, 総義㐘の安定装置としてオーバーデンチャータイプの補綴として用いら れるものに分けられる。

当院に扔いて双方とも数多くの症例を重ね, 良好な結果を得ら机ているが, それ以外の 応用法としてもミニインプラントを一般臨床に実用化させている。たとえば，通常のイン プラント一次オペ後の治癒を待つ期間に, ミニインプラントを義歯の維持装置として使用 している。これはあくまでも暫間的な処置として使用するものであり，いずれは抜去する のであるが, その期間だけでも十分な効果が得られ, 今では日常臨床に欠かせないものと なっている。

本稿では, これらの症例を紹介し, さらにミニインプラントの今後の展望についても考 察したい。

Key words : ミニインプラント mini-implant マイクロインプラント micro-implant, ミニスクリュー mini-screw アンカレッジ anchorage 


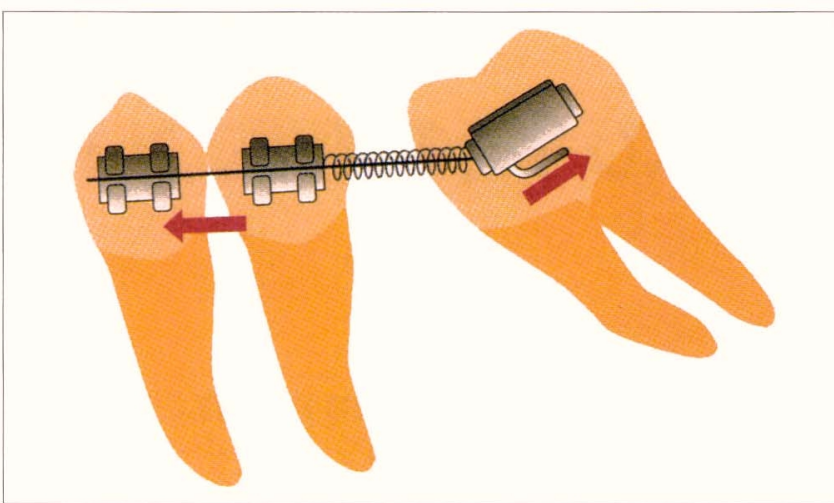

図 1 従来法の MTM（最後臼歯部のアップライト）（林 治幸著 「臨床医のためのインプラント矯正入門」より抜粋)

\section{緒言}

「ミニインプラント」とは, 一般的には矯正治療時に一 時的に矯正の力を加える固定源としての役目専用に作ら机 たごく細く短いチタン製のフィクスチャーのことを指す. しかし最近では広い意味も含めて，おもに下顎総義歯の維 持装置として用いられるフィクスチャーなども含まれるよ うである。

用語としては，「ミニインプラント」「マイクロインプラ ント」「ミニスクリュー」など全世界的にはいまだ統一さ れてはいないが，おもに当システムが開発された韓国を中 心に「マイクロインプラント」と呼ばれ，一方，欧米を中 心にした文献などでは「ミニインプラント」または「ミニ スクリュー」という用語で呼ばれることが多いようでであ る。著者は，客観的な見地で考えた上で，国際的にも通用 するであろうと思われる「ミニインプラント」という用語 を用いて，当システムに対する臨床応用と，今後の展望に ついて考察したい.

ミニインプラントは最近とくに米国での普及が著しく, 米国市場において 2007 年には約 $30 \%$ 以上の伸び率を示 し，その収益は2,000万ドルを越えたという”。この伸び 率は通常のインプラントを越えており，ミニインプラント の需要がいかに高まってきているか，ということを示す何 よりの訨拠であると思われる。ミニインプラントは通常の インプラントに比べて，(1)麻酔が少量で済む，(2)1回の処 置で完了する，(3)来院当日に摂食が可能，(4)フラップレス で処置できる，(5)疼痛がほとんどない，などの利点がある ため, 通常のインプラントの経験が浅い臨床医でも取り掛 かりやすいことが，世界的にもこれだけ普及してきている 要因ではないかと考えられる。

このミニインプラントを数年前から臨床に取り入れてか

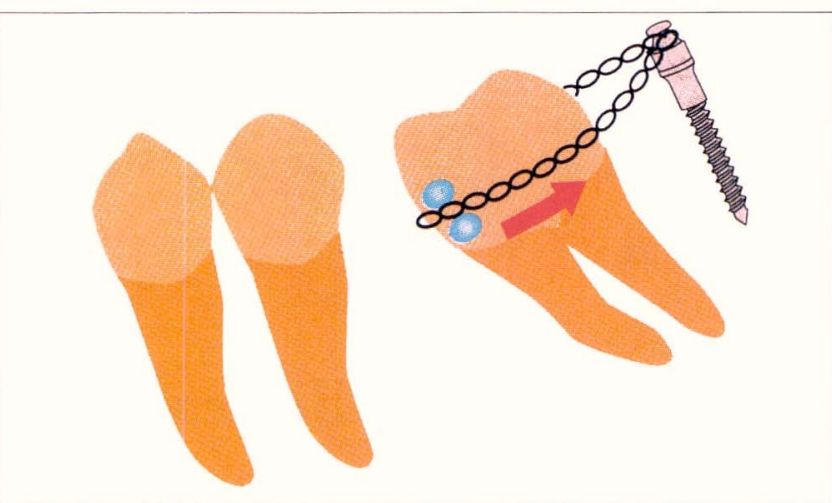

図2 ミニインプラントを用いた MTM (最後臼歯部のアップライト) （林 治幸著：「臨床医のためのインプラント矯正入門」より抜粋）。

ら，著者のMTMに対する考え方は劇的に变化した。

たとえば，われわれ歯科医師がもっとも頻繁に遭遇する であろう症例のひとつに，「下顎第一大自歯の欠損による 第二大的歯の近心傾斜」というものがある。この問題を解 決するためには，今までの MTMでは各歯牙にブラケット を装着し，時には反対側まで固定源を求めながら，当該歯 をコイルスプリングを用いてアップライトさせていく，と いう方法が一般的な考えであった。しかしながら，この場 合だと下顎小臼歯部にアンカレッジロスのトラブルを起こ すというリスクを回避することができなかった2（図１）. これが，たとえばミニインプラントを用いて近心傾斜した 下顎第二大拍歯をアップライトさせる場合には，従来法の MTM と比べて，以下のような利点が挙げられる22 (図2).

1. 可能な限り小さな装置で済むため, 患者に受け入れ てもらいやすい

2. 従来法のMTMにありがちなアンカレッジロスのト ラブルがなく，動かしたい歯に加わる矯正力だけに 注意すればよいか

3. 埋入が簡単で術式が簡便である

4. 矯正治療の途中で再埋入がいつでも可能である

5. 目標が達成され不要になれば，いつでも簡単に除去 できる

これらの利点をふまえたうえで, 著者が日常の臨床で応 用している当システムの症例をいくつか紹介させていただ きたい.

\section{症例}

I. 矯正治療で用いるミニインプラント

症例：54 歳, 女性

初診：平成 18 年 3 月 13 日

主訴：「左側でまったく物が噛めない」 

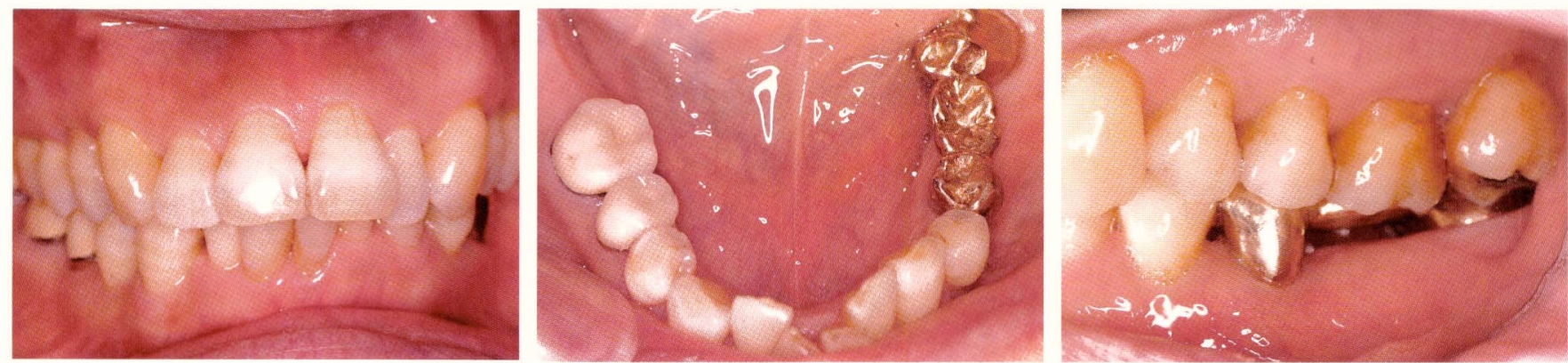

図 3 左下のブリッジは，歯牙が著しく舌側傾斜されたまま補緅処置が施されているためすれ違い咬合になっており，まったく物が噛めない状 態である.

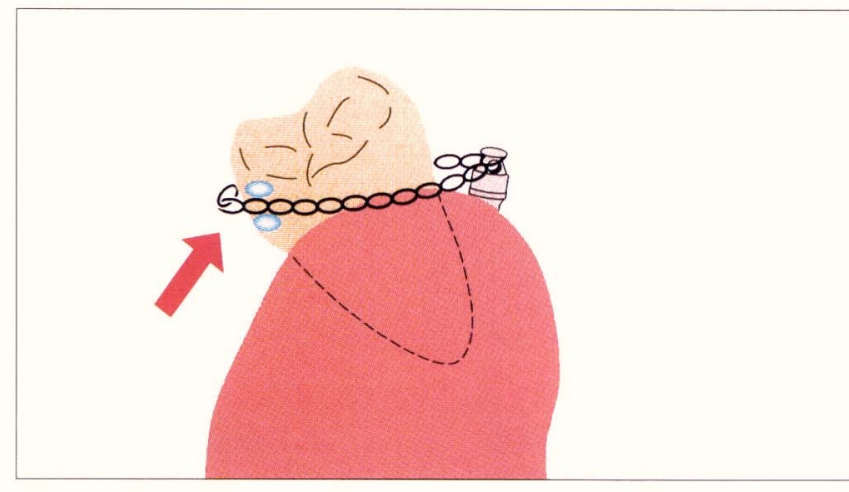

図 4 傾斜移動を行う場合の埋入位置とパワーチェーンのかけ方 (林 治幸著：「臨床医のためのインプラント矯正入門」より抜粋）.

\section{1. 口腔内所見（図 3)}

左側は完全なすれ違い咬合を呈している。上顎第二大臼 歯は煩側傾斜しており，また，下顎曰歯部には他院にて治 療をうけたゴールドブリッジが装着されているが，下顎左 側第二大臼歯が著しく舌側傾斜しているまま補綴を行って

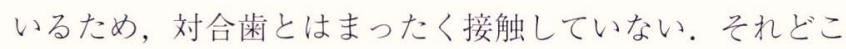
ろかポンティック部でも対合歯との接触がなく，第二小臼 歯部での咬合接触が最後方となっている.

\section{2. 診断結果}

著者はまず診断用模型（Diagnostic Wax-up）を製作し， この咬合をどこまで回復できるかを診断した。その結果， 上下の最後臼歯部は咬合高径が不十分であることが判明し たため，残念ではあるが上下最後臼歯を便宜抜䯣し，歯冠 高径の短い補経物を装着すれば，ミニインプラントによる MTM を用いた咬合回復が可能と判断した。その旨を患者 に説明し，治療の承諾を得るにいたった。

\section{3. 傾斜移動について}

ミニインプラントを用いた傾斜移動で歯牙を移動させる 場合の埋入部位の設定理論はいたってシンプルである。歯 を動かしたい方向の, 歯澒部から約 $3 \sim 5 \mathrm{~mm}$ 離机た部分 に埋人すればよい。そしてそのミニインプラントにパワー

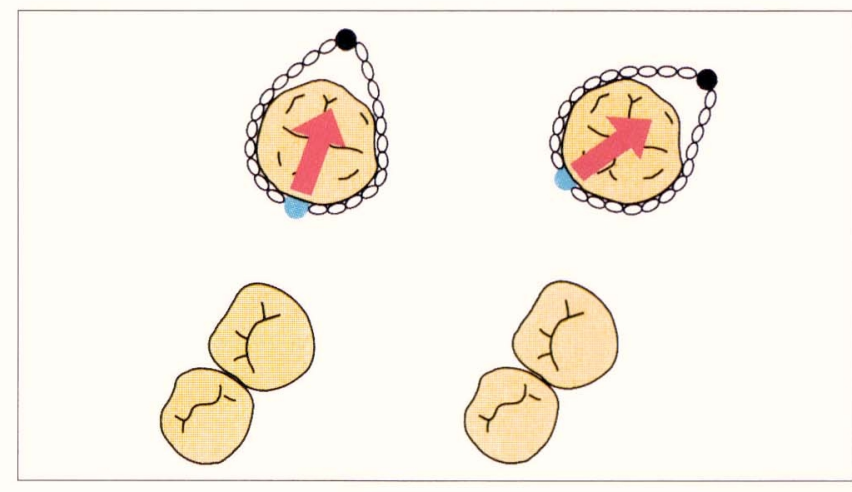

図 5 動かしたい方向に向かってミニインプラントを埋入させる （林 治幸著：「臨床医のためのインプラント矯正入門」より抜粋）.

チェーンをかけて当該歯を一周させ，ふたたびミニインプ ラントにかければ，パワーチェーンの力によって歯牙はそ の方向に向かって傾斜移動していく(図 4, 図 5).

途中で歯を動かす方向を訂正したい場合，または歯が移 動したことによってミニインプラントにぶつかり始めたと きなどは，ミニインプラントを抜去して再埋入すればよい.

\section{4. 治療経過}

たとえば㚘側傾斜している上顎第二大臼歯を元に戻す場 合，著者は最初は当該茵の近心隅角付近の口蓋㐘肉に埋入 していたが，歯牙が傾斜移動するにしたがって手前の歯で ある第一大臼歯に近付き過ぎていることがわかった。その ため，今度はミニインプラントを一度抜去して遠心隅角付 近の口蓋歯肉に再埋入している。これで約 1 力月半で当該 歯を目標とする位置まで動かすことができた。その後はパ ワーチェーンを弱い力で保持し，歯が後戻りしないよう約 2 力弱の保定期間を設けたうえで，ゴールドクラウンに て最終補経を行った(図6)。

一方下顎は，まず第三大臼歯は咬合に関与しておらず， しかも上顎歯肉にすでに接触しているほど廷出していたた め抜歯した。ゴールドブリッジを切断して第二大印歯の抜 髄処置を行った後，当該歯の遠心煩側部にミニインプラン 

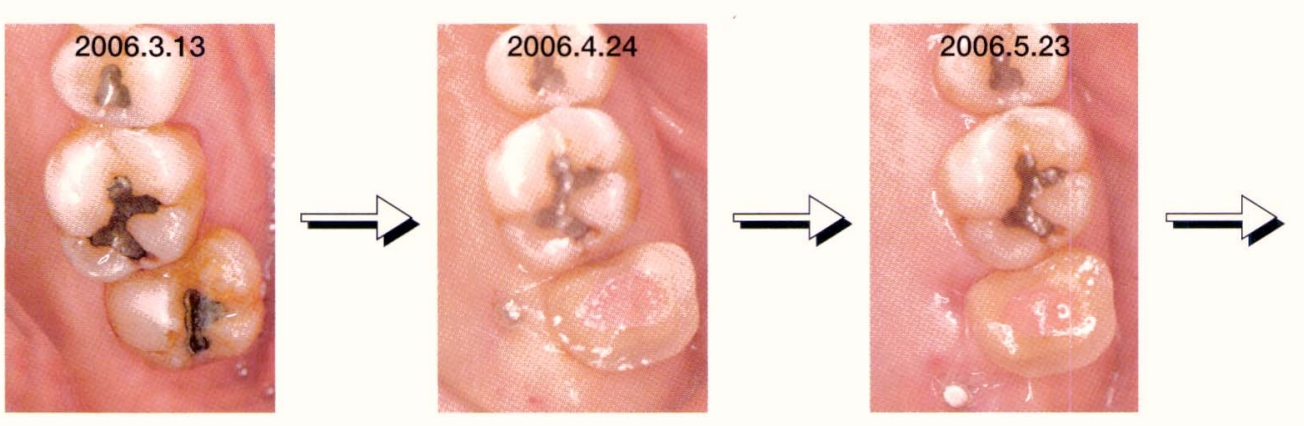

図 6 著しく頬側傾斜している 上顎左側第二大臼歯部の口蓋歯 肉にミニインプラントを埋入 し, パワーチェーンのカでアッ プライトした。途中でミニイン プラントは埋め替えている.
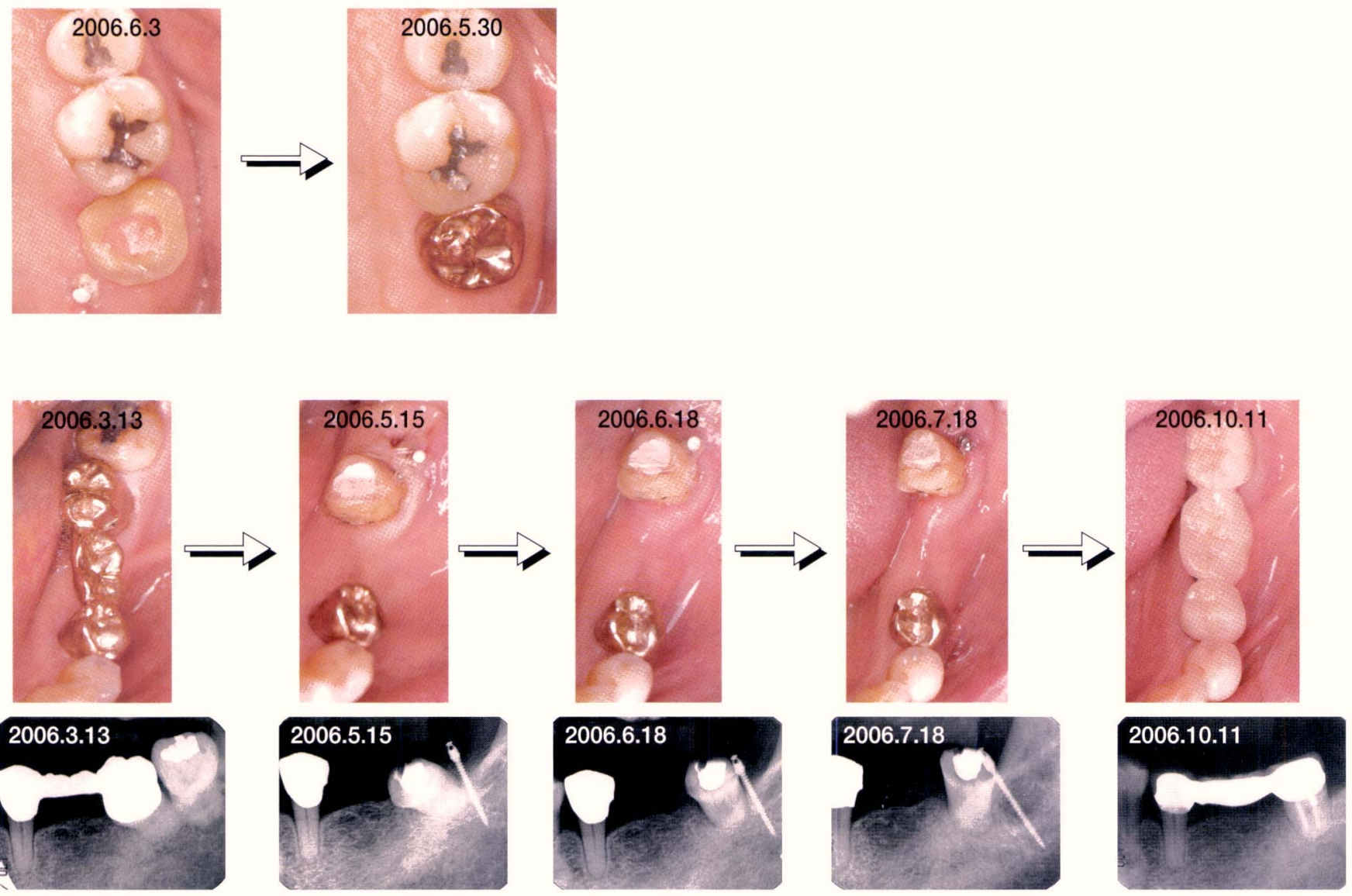

図 7 著しく舌側傾斜している下顎左側第二大臼歯部の頬側歯肉にミニインプラントを埋入し、パワーチェーンのカでアップライトした。途中 でミニインプラントは埋め替えている.

トを埋入し，歯牙移動を開始した。途中で歯が移動したこ とによりミニインプラントにぶつかってきので，何度かさ らに頬側へと再埋入した。こちらも約 2 力月ほどで目標と した位置まで踈を移動できた。その後ミニインプラントを 抜去してプロビジョナルレストレーションにてさらに約 2 カ月ほど保定したのちに，セラミックブリッジにて最終 補綴を行った (図7)。その結果, 大鼠歯部でも咬合でき るようになり，患者は「まったく噛めなかった左側で何で も噛めるようになった」とたいへん満足した（図８）. 190 |咬み合わせの科学
II . 補緅治療で用いるミニインプラント

同じミニインプラントでも, 補綴治療で用いる場合もあ る。適応症は限られてくるが, おもに下䪽総義歯のオー バーデンチャータイプの維持装置として用いることができ る。通常は，左右オトガイ孔間に4本のミニインプラント を埋入し，義柬の前茵部床下粘膜面にこれと呼応するメ夕 ルハウジングを埋め达んで義㐘を安定させるものである. この方法でミニインプラントを用いる場合, 従来のインプ ラントと比べて以下のような利点がある. 


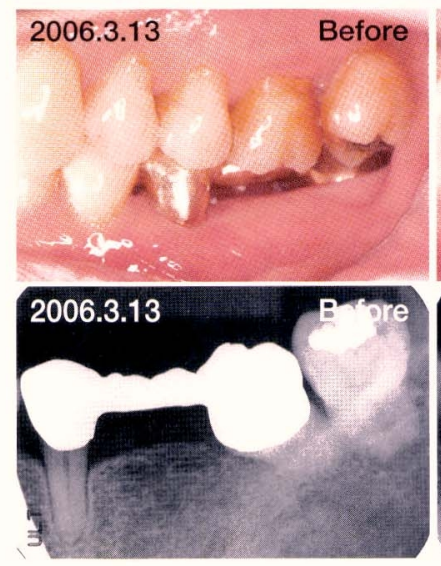

図 8 術前および術後写真

1.フラップレスで行うため外科的侵襲が少なく，高齢患 者にも安心して応用できる

2. 骨幅が狭く従来のインプラントが埋入できない場合で も適応できる

3. 即時荷重がかけられるため, その日から義歯を使うこ とができる

4. 治療費が安くすむため, 患者にも勧めやすい

症例：83歳 女性

初診:平成 15 年 10 月 4 日

主訴：「下の総入れ歯が安定しない」

1. 現症

患者は，それまでも数件の歯科医院にて下顎総義粹を製 作してきたがどれも満足しなかったとのこと、歯科医院で の義歯製作を繰り返すという，いわゆる「デンチャーコレ クター」であった。

\section{2. 診断結果}

咬合床内面の形態からもわかると扣り，下唨画側の田桠 部は歯槽堤がほぼ平坦で，義歯が安定させられる要素が志 しい。そこでミニインプラントによって義柬の維持安定を はかることを提案させていただき，全身状態を把握するた めに内科医と連携を取りながら，治療を進めていくことに した。

\section{3. 治療経過}

下顎総義歯をセットする日に，局所麻酔下にて下顎前歯 部に 4 本のミニインプラントを埋人した。術中はモニタ一 を装着して血圧や心電四を把握しながら進めたが，通常の 局所麻酔下で，約 20 分程度で 4 本のミニインプラントを 埋入することができた。そのため外科的侵襲もほとんどな く治療を終えることができた。埋入した日から即時荷重を

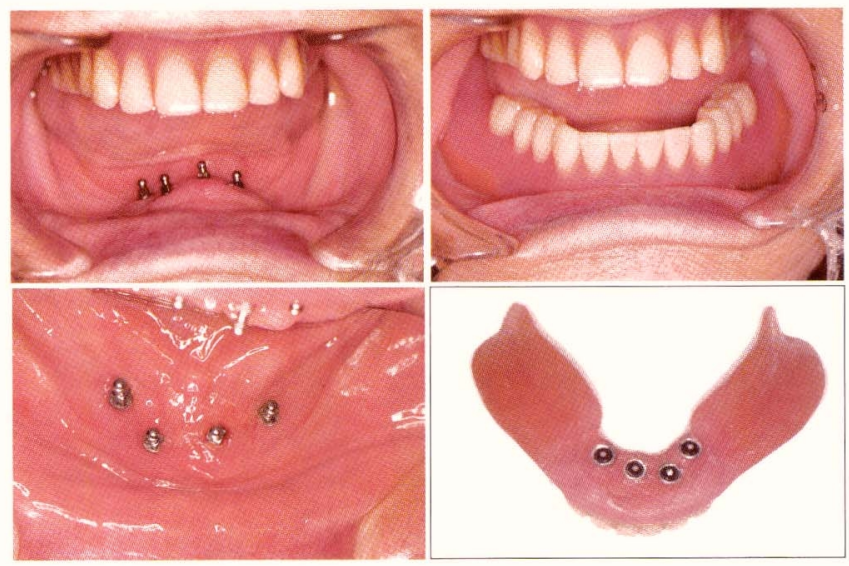

図 9 下顎前歯部に 4 本のミニインプラントを埋入して下顎総義歯 の維持装置として使用した症例

かけ，患者には新しい下顗総義歯を使用してもらった。

患者は，義歯が動かず一定の位置で安定しているので 「数十年ぶりに何でも䛧めるようになった」とたいへん喜 んだ。その後約 4 年の月日が経っているが，今のところ何 の問題もなく患者は義歯を使用している(図9).

III．応用編〜暫間的にミニインプラントを応用する方法〜 さらに応用編として，著者は通常のインプラント治療の 際にこのミニインプラントを暫間的に使用する場合もあ る。たとえば，臼歯部遊離端の複数歯欠損にインプラント 治療老施した場合，一次手術が終了してオッセオインテグ レーションが確立されるまでの治癒期間の間，フィクス チャー間の適当な位置にミニインプラントを 1 本埋人し， このミニインプラントで仮義㐘の咬合圧のほとんどを負担 させるというお法を取っている。

このいわゆる「暫間ミニインプラント」を応用すると， 以下のような利点がある

1. インプラントー次手術後, 最終補綴にとりかかるまで の間，今まで使用していた義歯をそのままお使いいた だくことができる

2. 咬合圧を義歯下のミニインプラントがすべて負担する ため，骨内のインプラント（フィクスチャー）に余分 な負担をかけることがない

3.オッセオインテグレーションが確立されるまでの間, わずか数力月間だけ持ってもらえればよい

4. 二次手術を行い上部構造を取り付ける際にいつでも抜 去できる

症例：54歳, 女性

初診: 平成 19 年1月17日 


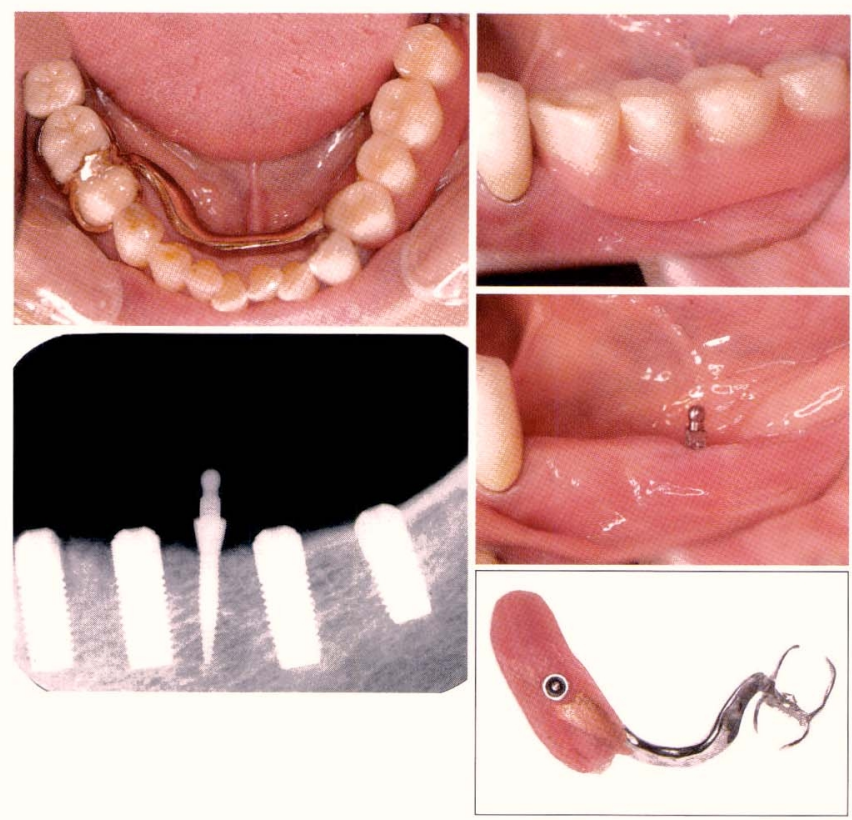

図 10 インプラントー次手術が終了してオッセオインテグレーショ ンが確立されるまでの治癒期間の間, フィクスチャー間の適当な位 置にミニインプラントを 1 本埋入し，このミニインプラントで仮義 歯の咬合圧のほとんどを負担させている症例。

主訴：「左下奥歯にインプラント希望」

\section{1. 治療経過}

当院にて左下臼歯部の欠損部にアストラテックインプラ ントを 4 本埋入した。そしてこのうち，2本目と 3 本目の フィクスチャー間にミニインプラントを 1 本埋入して，使 用中の局部床義歯の粘膜面にメタルハウジングを取り付け て，一次手術後も引き続き義歯を使えるようにした（図 10).

このままの状態で約 4 力月待ち, 二次手術を行ってア バットメント (Healing Abutment Zebra) を取り付ける際に ミニインプラントを除去した。その日のうちにZebraア バットメントにプロビジョナルレストレーションを取り付 けた。 そのため患者は, インプラントの治療中, 歯がない ままで州ることは一日もなく治療を進めていくことが可能 であった。

\section{考察}

現在急速に普及しつつあるミニインプラントであるが， 今後さらに考察さ机るべき点が多くある。そこで著者は, 既出の数多くの論文の中から「今わかっていること」とま とめ, 今後の展望について考察を行ってみた。

まずは「ミニインプラントの即時荷重は是か非か？」と いう問題である。これはよく著者も質問を受ける内容であ
るが，Melson.et al ${ }^{4)} ら の$ 文献をはじめ多くの実験論文が 「即時荷重をかけても問題ない」と述べている。日本国内 のメーカーによっては「数週間は荷重をかけないほうが良 い」と謳っているところもあるが，著者は今まで数多くの ミニインプラント症例をすべて即時荷重にて行ってきた が，まったく問題なく良好な結果を得ている.

次によく比較検討される問題が，「ミニインプラントの 直径は何 $\mathrm{mm}$ が望ましいか? という話題である。現在は 国内でも数多くのメーカーがミニインプラントを販売して いるが, どのメーカーのミニインプラントも直径約 $1 \mathrm{~mm}$ 程度から約 $2.5 \mathrm{~mm}$ 程度のものまで実にさまざまなバリ エーションがある。もちろん細い万が外科的侵襲は少ない ので用いやすいが，維持力がなければ意味がない。2003 年の Miyawaki.et $\mathrm{al}^{5}$ らの実験では, 直径が $1.0 \mathrm{~mm}, 1.5 \mathrm{~mm}$, $2.3 \mathrm{~mm}$ の 3 種類のグループに分けた合計 134 本のミニイン

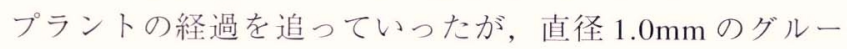
プの荷重 1 年後の成功率は, 直径 $1.5 \mathrm{~mm}$ および $2.3 \mathrm{~mm}$ グ ループのそれと比べると極端に悪かったことが判明した。 この実験結果から，ミニインプラントの直径は少なくとも $1.5 \mathrm{~mm}$ 以上はあるほうが望ましいと考える。また，ミニイ ンプラントには大きくわけてテーパータイプのものとシリ ンダータイプのものがあるが，2006 年の Yano.et $\mathrm{al}^{6)}$ らの 実験によると，テーパータイプのものがシリンダータイプ のものより良好な初期固定が得られたとの結果が出てい る。以上のことから，皮質骨に初期固定を求めるには，埋 入時にだんだん径が太くなるテーパータイプの方が望まし いこと考える.

また「脱落することはないのか？」という質問もよく受 けるが，正直，ミニインプラントが脱落してしまう症例は 稀ではあるが存在する。とくに上顎骨の場合にそのリスク は高まってくる. 既出の数多くの論文などから, ミニイン プラントの成功率 (非脱落率) は従来のインプラントに遜 色ない程度の成功率を得てはいるものの7，患者にはつね に「脱落する可能性もある」ということは事前に説明して おかなけ机ばいけない。

しかしながら，ミニインプラントの場合には，たとえ脱 落したとしても，亦ぐまた近接した部位に再埋入すること が可能であるため, それもまた逆説的な「利点」となり之 るのである。著者はミニインプラントを埋入する際には 途中から手動で回しながら埋入する。そのため, 手指に伝 わる抵抗力の大きさで, おおよその骨の硬さが判別できる ようになった。そこで，たとえば埋入時に明らかに抵抗力 が少なくスルスルと入っていく感覚を感じた場合には脱落 するリスクが高いと考え，その場でミニインプラントを一 
度抜き，2〜3mm 離れた部位に再埋入するようにしてい る.すると，2〜3mm 離れただけでも意外と硬い部分を 発見するようなことが多い。このように「初期固定が難し い」と判断した場合には，「勇気ある再埋入」をすること によって，後に生じるトラブルを最小限にとどめることが できるようになる.

ミニインプラントのリスクファクターとしては, 従来の インプラントと同じく, やはりプラーク沈着による歯肉炎 症がわかっている。つまり長期にわたり良好な状態を維持 するためには，やはりミニインプラント周囲のプラークコ ントロールを適切に行う必要がある7).

\section{参考文献}

1) DENTAL TRIBUNE _The World's Dental Newspaper. Japan Edition,4 (7), July, 2008.

2）林 治幸 : 臨床医のためのインプラント矯正入門. 砂書房 (東京), 2007.

3）林 治幸：歯牙移動，歯牙移植，外科矯正を取りいれた補 緅処置一インプラントを矯正のアンカレッジとして利用す るー。デンタルダイヤモンド，363：157-163， 2002.

4) Melsen, B. and A. Costa : Immediate loading of implants used for orthodontic anchorage. Clin Orthod Res, 3 (1) : 23-8. 2000.

5) Miyawaki, S., I. Koyama, et al. : Factors associated with the stability of titanium screws placed in the posterior region for orthodontic anchorage. Am J Orthod Dentofacial Orthop, 124 (4) :373-8 . 2003

\section{結論}

このように，ミニインプラントには数々の使用法があり， 使い方次第では無限の可能性を秘めている画期的な方法で あるといえる。

しかしながら, 従来のインプラントに比べてその歴史が まだ浅いことと, 各国の各メーカーが新システムを続々と 開発中のため，世界的に確立されたグローバルスタンダー ドがまだ存在していない，というのも事実である。

今後さらなる研究が必要であり, より一層の発展を期待 したい.

6) Yano, S., M. Motoyoshi, et al. : Tapered orthodontic miniscrews induce bone-screw cohesion following immediate loading. Eur $\mathrm{J}$ Orthod, 28 (6) : 541-6, 2006.

7) Park, H. S., S. H. Jeong, et al. : Factors affecting the clinical success of screw implants use as orthodontic anchorage. Am J Orthod Dentofacial Orthop, 130 (1) : 18-25, 2006. 